\title{
Phytogeographical patterns of dry forests sensu stricto in northern Minas Gerais State, Brazil
}

\author{
DANIEL M. ARRUDA ${ }^{1}$, WALNIR G. FERREIRA-JÚNIOR ${ }^{2}$, \\ REINALDO DUQUE-BRASIL ${ }^{3}$ and CARLOS E.R. SCHAEFER ${ }^{4}$ \\ ${ }^{1}$ Universidade Federal de Viçosa, Departamento de Biologia Vegetal, Av. P.H. Rolfs, s/n, Centro, 36571-000 Viçosa, MG, Brasil \\ ${ }^{2}$ Instituto Federal de Educação, Ciência e Tecnologia do Sul de Minas Gerais, \\ Rod. Machado-Paraguassu, Km 3, Santo Antônio, 37750-000 Machado, MG, Brasil \\ ${ }^{3}$ Universidade Federal de Juiz de Fora, Instituto de Ciências Biológicas, \\ R. Sete de Setembro, 3500, Centro, 35010-173 Governador Valadares, MG, Brasil \\ ${ }^{4}$ Universidade Federal de Viçosa, Departamento de Solos, Av. P.H. Rolfs, s/n, Centro, 36571-000 Viçosa, MG, Brasil
}

Manuscript received on April 26, 2011; accepted for publication on May 29, 2012

\begin{abstract}
The Deciduous Complex that occurs in northern Minas Gerais State, Brazil, raises questions about the floristic affinities of these formations in relation to neighboring phytogeographical domains. Little is known about the identity of the seasonal forest formations that comprise this complex, or about its relationships to abiotic components, such as soils, topography and climate. This study aimed to recognize the patterns of floristic similarity of all studied fragments of dry forest of northern Minas Gerais with soil and climate attributes, based on the available database. Cluster analysis indicated the existence of two floristic groups that had clear associations with either the Koppen's BSh (semi-arid) or Aw (seasonal tropical) climates. Likewise, the subdivisions of these groups showed clear associations with the dominant soil classes in the region. The Red-Yellow Latosol is the dominant soil classes in the BSh climatic domain, seconded by alluvial areas associated with Fluvic Neosols. The Aw domain comprised a much varied set of soils: Nitosols, Argisols, Cambisols and Litholic Neosols, most derived from the Bambuí limestone/slate formation. The ecotonal nature of northern Minas Gerais State provides a complex interaction between the flora of neighboring phytogeographical domains. This, allied to pedogeomorphological factors, allowed a better understanding of the effects of late Quaternary climate changes for the Deciduous Complex evolution. We conclude that the Latosols under present-day semi-arid climates (BSh) are relicts of former wetter climates, during which humid forest (semideciduous) expansion took place. Later, these semideciduous forests were subjected to a much drier climate, when selection for deciduousness led to the present-days Deciduous Complex scenario.
\end{abstract}

Key words: climate, deciduous seasonal forest, ecotone, phytogeography, soil.

\section{INTRODUCTION}

The seasonally dry tropical forests, or seasonal deciduous forests, were classified by Veloso et al. (1991) as a vegetation type influenced by a markedly

Correspondence to: Carlos Ernesto Reynaud Schaefer E-mail: carlos.schaefer@ufv.br seasonal climate, with a rainy summer followed by a long dry period; there, most plants are totally deciduous in the dry season. Although the definition of dry forest by some authors includes shrub formations (bushland, scrub, and thicket), Caatinga savannas, and the semideciduous forests of the 
Atlantic domain (e.g. Pennington et al. 2006), in the present work we chose to restrict this designation only to deciduous forest formations (deciduousness above 50\%, sensu Veloso et al. 1991), which will be referred to in the text as dry forests sensu stricto (DF). Similar exclusion criteria were adopted by Gentry (1995) to analyze Neotropical DF.

In Brazil, DF are located within the Pleistocene Arch (Prado and Gibbs 1993) - an extensive range of natural forest areas extending from the northeastern Brazil (in the Caatinga domain) to the Brazilian southwest, and the dry lowlands of Bolivia and Paraguai ("Chaco"). The floristic relationships of different DF with these two neighboring domains were described by Oliveira-Filho et al. (2006) and Queiroz (2006).

When compared to moist or wet forests, DF have lower richness and primary productivity, which are directly related to reduced rainfall (Gentry 1995) and the seasonal nature of the environment (Murphy and Lugo 1986). Thus, the seasonality of the DF constraints and determines the biological activity, growth, reproduction, and species distribution (Murphy and Lugo 1986). Their seasonal nature is also an important factor in defining the macrogradient from humid-ombrophilous forests to seasonaldeciduous forests (Oliveira-Filho and Fontes 2000).

On a global scale, Murphy and Lugo (1986) suggested that DF would occur in areas with precipitation rates of $600-1,800 \mathrm{~mm} /$ year distributed along 4-9 months, with average annual temperatures ranging from 19 to $27^{\circ} \mathrm{C}$. On a regional scale of the present study, DF occur where annual precipitation ranges between 700-1,200 $\mathrm{mm}$, concentrated in 5-6 months, with temperatures varying between $14-19^{\circ} \mathrm{C}$ in the Espinhaço Mountain Range and between $26-31^{\circ} \mathrm{C}$ in the depression of the São Francisco and Verde Grande River valleys in northern Minas Gerais State (Antunes 1994). This state region is marked by a transition from a tropical rainy climate (covering most of the area) to a semi-arid zone to the north (Antunes 1994). Hence it represents a broad ecotonal zone.
Consistent with the transitional climate, the northern region of Minas Gerais is marked by the transition between three large phytogeographical domains: Caatinga (to the north); Cerrado (to the west); and Atlantic Forest (to the east). Due to the contact between these domains, this region is classified as a "tension zone" (Ab'Sáber 2003) or "ecotone", with mixed plant formations that are difficult to characterize and have complex floristic compositions distributed among various phytophysiognomies that change according to local topography and local edaphic conditions (Brandão 2000).

The identity of the DF formations and their associations with abiotic components (climate, topography and lithology) remain practically unknown and have not yet been investigated in any integrated or systematic manner. In light of this situation, and recognizing the complex distribution of DF in northern the Minas Gerais State, the present work examined the patterns of floristic similarity between several DF fragments and their association with edaphic and climatic factors.

\section{MATERIALS AND METHODS}

A database was produced by reviewing the scientific literature for floristic and/or phytosociological surveys in areas of dry forests (DF) sensu stricto in northern Minas Gerais State. This literature review included lists of arboreal species (using the inclusion criteria of plants with circumference at breast height equal to or greater than $15 \mathrm{~cm}$ ) from scientific surveys undertaken in the region as well as lists produced by the Forest Inventory of Minas Gerais (Mello et al. 2008) (Table I). Surveys undertaken in gallery forests were not included to avoid undesirable overlaps with the semideciduous flora.

The coordinates of each locality were overlaid on a map of soil classes produced during field expeditions and processed at the Geoprocessing Laboratory at the Universidade Federal de Viçosa (Fig. 1).

The Species List of Brazil's Flora (Forzza et al. 2010) database was used to standardize species 
nomenclature. Floristic comparison analyses were performed at the species level; and to ensure greater reliability of the results (and lessen any errors related to possible erroneous identifications) the same analyses were repeated at the genus level (Rodal et al. 2008). Matrixes were constructed using data concerning the presence of 396 species and 193 genera, representing 65 botanical families in 26 areas of DF in northern Minas Gerais, to aid identifying similar floristic groups. The matrixes were used in TWINSPAN divisive clustering analyses (Hill et al. 1975) and agglomerating
Cluster Analyses (Sneath and Sokal 1973), both employing the Jaccard similarity coefficient. These analyses were processed by the PC-ORD program for Windows version 5.1 (McCune and Mefford 2006).

The hierarchical groupings formed together with their preferential species, as indicated by the TWINSPAN analyses, were also analyzed in relation to the dominant soil classes and to the climate types described by Antunes (1994) for the region (the latter based on the classification system of Köppen) (Fig. 2).

TABLE I

Identification, geographical localization, and predominant soil class of the forest associations of 26 survey areas comprising the data bank of dry forests sensu stricto (DF) in northern Minas Gerais.

\begin{tabular}{|c|c|c|c|c|c|}
\hline Areas & Code & Latitude & Longitude & Predominant Soil Class & Reference \\
\hline Capitão Enéas I & Cap_1 & -16.1497 & -43.6997 & RLe - Litholic Neosol & Arruda et al. 2011 \\
\hline Capitão Enéas II & Cap_2 & -16.1575 & -43.6994 & RLe - Litholic Neosol & Arruda et al. 2011 \\
\hline Capitão Enéas III & Cap_3 & -16.1514 & -43.7219 & RLe - Litholic Neosol & Arruda et al. 2011 \\
\hline Jaíba I & Jai_1 & -14.9858 & -43.5209 & RUbe - Fluvic Neosol & Mello et al. 2008 \\
\hline Jaíba II & Jai_2 & -15.2936 & -43.9127 & CXbe - Haplic Cambisol & Mello et al. 2008 \\
\hline Jaíba III & Jai_3 & -15.3599 & -44.012 & CXbe - Haplic Cambisol & Mello et al. 2008 \\
\hline Januária I & Jan_1 & -15.5979 & -44.7098 & LVAd - Red-Yellow Latosol & Mello et al. 2008 \\
\hline Januária II & Jan_2 & -15.6092 & -44.7164 & LVAd - Red-Yellow Latosol & Sales et al. 2009 \\
\hline Juramento & Jur & -16.7722 & -43.6656 & PVAe - Red-Yellow Argisol & Santos et al. 2007 \\
\hline Juvenília I & Juv_1 & -14.4728 & -44.1917 & RLe - Litholic Neosol & Santos et al. 2007 \\
\hline Juvenília II & Juv_2 & -14.4344 & -44.1853 & RLe - Litholic Neosol & Santos et al. 2007 \\
\hline Juvenília III & Juv_3 & -14.4244 & -44.1719 & PVAe - Red-Yellow Argisol & Santos et al. 2007 \\
\hline Juvenília IV & Juv_4 & -14.4906 & -44.1842 & PVAe - Red-Yellow Argisol & Santos et al. 2007 \\
\hline Juvenília V & Juv_5 & -14.2758 & -44.1117 & LVAd - Red-Yellow Latosol & Santos et al. 2007 \\
\hline Manga I & Man_1 & -14.9333 & -44.0667 & LVAd - Red-Yellow Latosol & Madeira et al. 2009 \\
\hline Manga II & Man_2 & -14.8231 & -43.9321 & RUbe - Fluvic Neosol & Mello et al. 2008 \\
\hline Manga III & Man_3 & -14.8131 & -43.9319 & RUbe - Fluvic Neosol & Mello et al. 2008 \\
\hline Manga IV & Man_4 & -14.872 & -43.982 & CXbe - Haplic Cambisol & Mello et al. 2008 \\
\hline Matias Cardoso I & Mat_1 & -14.7466 & -43.8185 & LVAd - Red-Yellow Latosol & Mello et al. 2008 \\
\hline Matias Cardoso II & Mat_2 & -15.0675 & -43.7606 & LVAd - Red-Yellow Latosol & Mello et al. 2008 \\
\hline Matias Cardoso III & Mat_3 & -14.8546 & -43.819 & LVAd - Red-Yellow Latosol & Mello et al. 2008 \\
\hline Matias Cardoso IV & Mat_4 & -14.9769 & -43.9046 & LVAd - Red-Yellow Latosol & Mello et al. 2008 \\
\hline Montes Claros I & Moc_1 & -16.7492 & -43.9036 & NXe - Haplic Nitosol & Santos et al. 2007 \\
\hline Montes Claros II & Moc_2 & -16.5792 & -43.7692 & NXe - Haplic Nitosol & D.M. Arruda, unpublished data \\
\hline Montalvânia & Mon & -14.4689 & -44.5161 & LVAd - Red-Yellow Latosol & Santos et al. 2007 \\
\hline Pai Pedro & Pai & -15.44 & -42.9849 & LVAe - Red-Yellow Latosol & Mello et al. 2008 \\
\hline
\end{tabular}




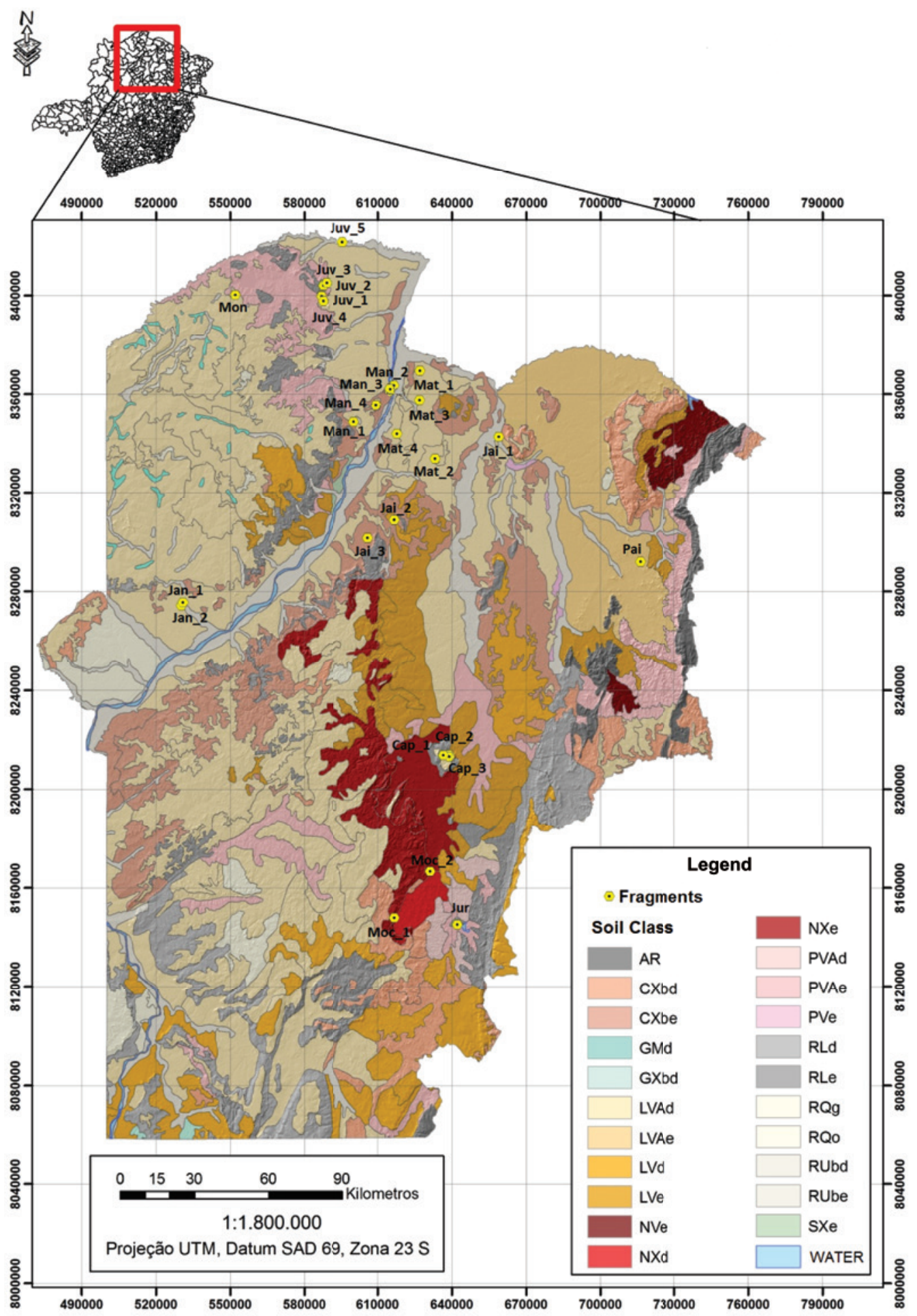

Figure 1 - Exploratory soil map (predominant soil class in associations) indicating the location of 26 fragments of dry forests sensu stricto (DF) in northern Minas Gerais incorporated into the database. The areas are identified by the codes listed in Figure 1. The soil associations are labelled: AR - rock outcrop, CXb - Cambisol, GM - Melanic Gleysol, GX - Haplic Gleysol, LVA Red-Yellow Latosol, LV - Red Latosol, NV - Red Nitosol, NX - Haplic Nitosol, PVA - Red-Yellow Argisol, PV - Red Argisol, RL - Litholic Neosol, RQ - Quartzarenic Neosol, RUb - Fluvic Neosol, SX - Planosol, e - eutrophic, d - dystrophic. 


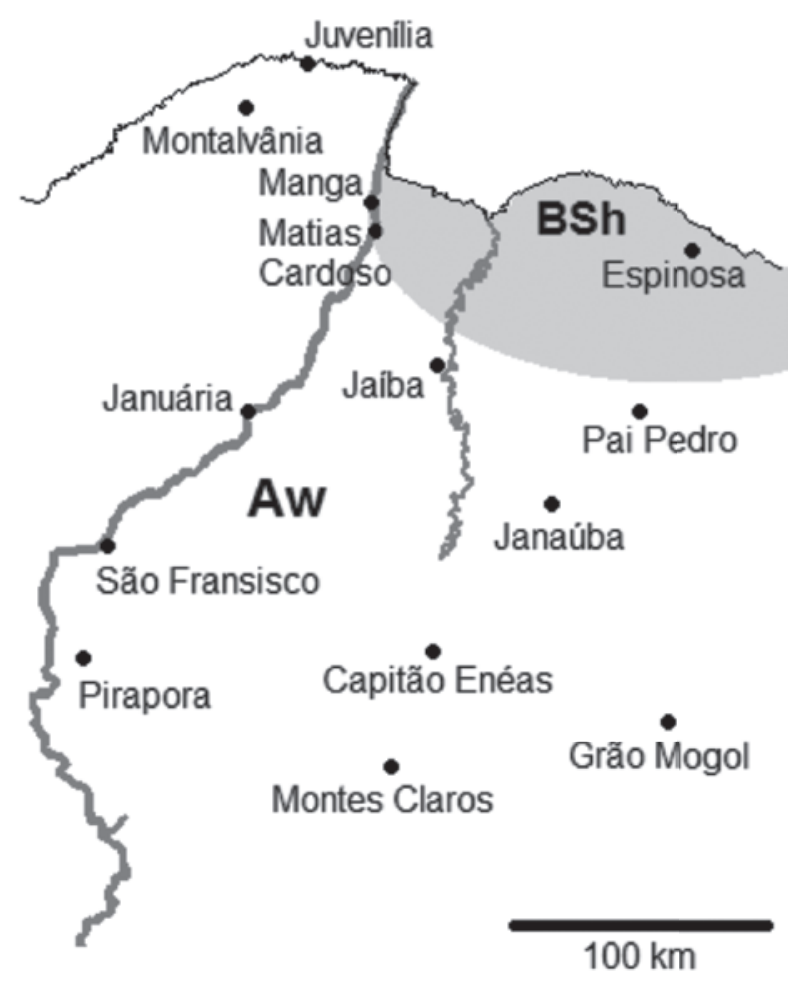

Figure 2 - Approximate spatial distribution of climatic types identified for the northern region of Minas Gerais, according to the Köppen climate classification (redrawn from Antunes 1994).

\section{RESULTS}

Divisive clustering analyses at the species level first showed a division into two large dry forest (DF) groups (eigenvalue 0.49) (Fig. 3). These two groups have most areas distributed in different climatic domains. Likewise, the subgroups formed had strong associations with the predominant soil classes in their respective areas.

Some species were shared between different areas, although specific sets of species proposed by the TWINSPAN analysis were observed to be associated with certain environments (Table II). In addition, some species stood out due to their frequent occurrence in these groups, and even though they might occasionally occur in another group, they were strong indicators of the associations in question. Similarly, commonly occurring species with no preference for either

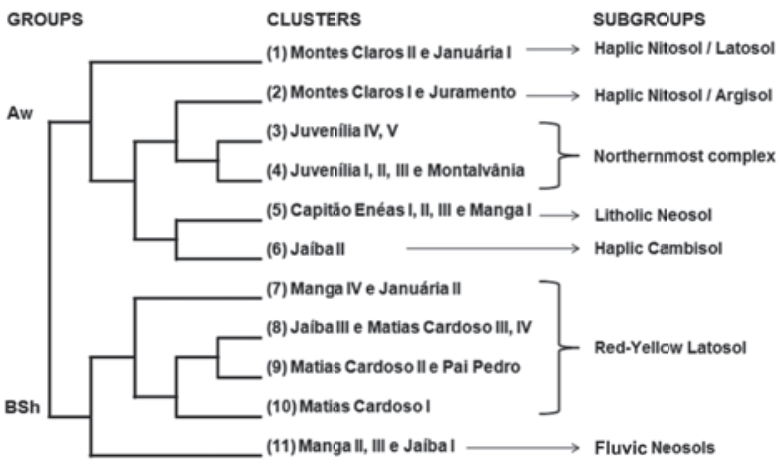

Figure 3 - Dendrogram of the relationships between 26 areas of dry forest sensu stricto (DF) in northern Minas Gerais as produced by the divisive clustering analyses of 396 species. The numbers in parentheses correspond to the clusters cited in the text.

groups were considered typical DF species. Already, exclusive species of specific groups are indicated in bold type in Table II.

The first main group was formed by the localities in the seasonal tropical climate domain (Aw), where covered large areas on many different soil classes; the second main group was formed by localities strongly associated with the semi-arid climate domain (BSh), developed on Red-Yellow Latosols (according to the Brazilian System of Soil Classification) or Fluvic Neosols (Alluvial soils).

The Aw group was divided into five subgroups. The first subgroup (corresponding to cluster 1) was found in areas of Haplic Nitosols and Latosols (Montes Claros [II] and Januária [I] respectively) and differed considerably from all of the others (eigenvalue 0.44). The second subgroup (corresponding to cluster 2) represented by areas located in the southernmost region (including Montes Claros [I] and Juramento) on Haplic Nitosols and Argisols (Podzolic soil) respectively. This latter group has a great floristic affinity with the third subgroup (corresponding to clusters 3 and 4) representing areas of dry forest located in the northernmost part of the state (in the municipalities of Juvenília [I, II, III, IV and V] and Montalvânia) on varying soil classes, 


\section{TABLE II}

Determinant species of the groups formed by TWINSPAN analysis. The indicator species of specific groups are indicated in bold type. Species with only low occurrence between the areas of the groups do not appear in the table.

\section{Typical species of Dry Forest sensu stricto}

Anadenanthera colubrina, Aralia warmingiana, Aspidosperma pyrifolium, A. subincanum, Astronium fraxinifolium, Bougainvillea praecox, Cavanillesia umbellata, Cereus jamacaru, Combretum duarteanum, C. leprosum, Commiphora leptophloeos, Dilodendron bipinnatum, Enterolobium contortisiliquum, Eugenia florida, Goniorrhachis marginata, Lonchocarpus costatus, Machaerium acutifolium, M. villosum, Mimosa tenuiflora, Myracrodruon urundeuva, Peltophorum dubium, Piptadenia viridiflora, Platypodium elegans, Platymiscium floribundum, Schinopsis brasiliensis, Senna spectabilis, Spondias tuberosa, Sterculia striata, Tabebuia chrysotricha, T. roseoalba, Triplaris gardneriana, Trichilia hirta

\section{Group Aw}

Acacia bahiensis, Apuleia leiocarpa, Bauhinia forficata, Cedrela fissilis, Celtis iguanaea, Chloroleucon tenuiflorum, Cnidoscolus pubescens, Coutarea hexandra, Guazuma ulmifolia, Machaerium aculeatum, M. brasiliense, M. scleroxylon, Maclura tinctoria, Poincianella microphylla, Pseudobombax simplicifolium, Pterogyne nitens, Randia armata, Syagrus oleracea, Talisia esculenta, Zanthoxylum riedelianum

\section{Group BSh}

Acacia polyphylla, Acosmium lentiscifolium, Albizia inundata, Amburana cearensis, Annona leptopetala, Bougainvillea glabra, Casearia selloana, Centrolobium sclerophyllum, Chloroleucon foliolosum, Cordia incognita, Cordia trichotoma, Cyrtocarpa caatingae, Fridericia bahiensis, Galipea ciliata, Geoffroea spinosa, Manihot anomala, Pereskia bahiensis, Pityrocarpa moniliformis, Plathymenia reticulata, Poeppigia procera, Poecilanthe ulei, Poincianella pluviosa, Ptilochaeta bahiensis, Spondias venulosa, Stillingia saxatilis, Sweetia fruticosa, Tabebuia heptaphylla, T. impetiginosa, T. spongiosa, Terminalia fagifolia

\section{Subgroup I: Dry Forest sensu stricto on Haplic Nitosol and Latosol}

Aspidosperma subincanum, Bauhinia cheilantha, B. rufa, Machaerium villosum, Tabebuia impetiginosa, Terminalia argentea

\section{Subgroup II: Dry Forest sensu stricto on Haplic Nitosol and Argisol}

Acrocomia aculeata, Cordiera concolor, Annona crassiflora, Astronium fraxinifolium, Brosimum gaudichaudii, Byrsonima verbascifolia, Cariniana estrellensis, Casearia rupestris, Cecropia pachystachya, Copaifera langsdorffii, Croton urucurana, Curatela americana, Cybistax antisyphilitica, Dilodendron bipinnatum, Eriotheca pubescens, Eugenia dysenterica, Genipa americana, Heteropterys byrsonimifolia, Inga sessilis, Jacaranda brasiliana, Leptolobium dasycarpum, Lithraea molleoides, Machaerium opacum, Myrciaria floribunda, Platypodium elegans, Qualea grandiflora, Rhamnidium elaeocarpum, Roupala montana, Solanum lycocarpum, Terminalia argentea, Terminalia brasiliensis

\section{Subgroup III: Dry Forest sensu stricto on Northernmost Complex}

Cavanillesia umbellata, Cereus jamacaru, Chloroleucon tenuiflora, Cnidoscolus pubescens, Combretum leprosum, Commiphora leptophloeos, Goniorrhachis marginata, Machaerium brasiliense, Mimosa tenuiflora, Poincianella microphylla, Pseudobombax simplicifolium, Sterculia striata, Syagrus oleracea

\section{Subgroup IV: Dry Forest sensu stricto on Litholic Neosol}

Acacia polyphylla, Aspidosperma pyrifolium, Bougainvillea praecox, Casearia decandra, Cavanillesia umbellata, Celtis iguanaea, Cnidoscolus pubescens, Coccoloba schwackeana, Combretum duarteanum, Leucochloron incuriale, Lonchocarpus campestris, Machaerium scleroxylon, Piptadenia gonoacantha, Platymiscium floribundum, Platypodium elegans, Pterogyne nitens, Randia armata, Sapium obovatum, Syagrus oleracea, Tabebuia ochracea, Ziziphus joazeiro 
TABLE II (continuation)

\section{Subgroup V: Dry Forest sensu stricto on Haplic Cambisol}

Albizia inundata, Albizia polycephala, Allophylus racemosus, Annona cornifolia, Apuleia leiocarpa, Cabralea canjerana, Casearia gossypiosperma, Cedrela fissilis, Cordia ecalyculata, Dalbergia frutescens, Daphnopsis brasiliensis, Dilodendron bipinnatum, Guapira hirsuta, Guapira opposita, Jatropha mollissima, Machaerium villosum, Manihot caerulescens, Ouratea hexasperma, Poincianella pyramidalis, Randia armata, Sparattosperma leucanthum, Tabebuia reticulata, Terminalia fagifolia

Subgroup VI: Dry Forest sensu stricto on Red-Yellow Latosol

Acacia langsdorffii, Acosmium lentiscifolium, Aegiphila sellowiana, Albizia polycephala, Annona leptopetala, Aralia warmingiana, Aspidosperma multiflorum, A. pyrifolium, Barnebya harleyi, Bauhinia forficata, Ceiba pubiflora, Centrolobium sclerophyllum, Cereus jamacaru, Chloroleucon foliolosum, Coccoloba schwackeana, Cochlospermum vitifolium, Commiphora leptophloeos, Cordia trichotoma, Croton argyrophylloides, Cyrtocarpa caatingae, Dalbergia cearensis, Dalbergia frutescens, Dilodendron bipinnatum, Fridericia bahiensis, Galipea ciliata, Guapira tomentosa, Jatropha mollissima, Luetzelburgia Andrade-limae, Machaerium acutifolium, Mimosa tenuiflora, Peltophorum dubium, Platypodium elegans, Platymiscium floribundum, Poincianella pluviosa, Pseudobombax tomentosum, Ptilochaeta bahiensis, Spondias mombin, Spondias venulosa, Stillingia saxatilis, Tabebuia aurea, T. chrysotricha, T. selachidentata, T. spongiosa, Terminalia fagifolia, Vitex polygama

Subgroup VII: Dry Forest sensu stricto on Fluvic Neosols

Aspidosperma cuspa, A. subincanum, Campomanesia xanthocarpa, Coccoloba mollis, Enterolobium contortisiliquum, Erythroxylum cuneifolium, Jatropha palmatifolia, Lonchocarpus cultratus, Machaerium stipitatum, Myrcia guianensis, Ruprechtia laxiflora, Sideroxylon obtusifolium, Simira sampaioana, Spondias tuberosa, Triplaris gardneriana, Trischidium mollis, Ziziphus joazeiro

including Litholic Neosols, Argisols, and Latosols. The fourth subgroup (corresponding to cluster 5) comprised principally areas of Litholic Neosols (in the municipality of Capitão Enéas [I, II and III]), with only a single area of Red-Yellow Latosols (Manga [I]). The fifth subgroup (corresponding to cluster 6) was represented only by a single area of Haplic Cambisols (Jaíba [II]).

The BSh group was divided into two subgroups. The first, represented by clusters 7 , 8, 9 and 10, was mainly formed by areas of RedYellow Latosols (including Matias Cardoso [I, II, III, IV], Pai Pedro and Januária [II]); however, areas of Haplic Cambisols (Jaíba [III] and Manga [IV]) were also included, although all in soil associations with latosols. The second subgroup comprised forests growing on Fluvic Neosols (Manga [II and III] and Jaíba [I]) and corresponded to cluster 11 in Figure 3. This group comprise very heterogeneous soil associations, including Fluvic Neosols, Planosols, Cambisols and Latosol, all associated with floodplain landscapes (várzeas seasonally flooded forests) and terraces along the São Francisco and Verde Grande rivers.

Similarity analysis at the genus level (Fig. 4) confirmed the two large groups identified at the species level analysis, demonstrating the reliability of these groups, even though slightly different methods were used. This analysis had a high cophenetic correlation index (0.91), indicating low distortions between the real data and the dendrogram.

\section{DISCUSSION}

The fact that some areas did not correlate with expected climatic domains (e.g. Januária II, Jaiba III and Pai Pedro in the BSh domain, and Manga I and Jaiba II in the Aw domain) can be 


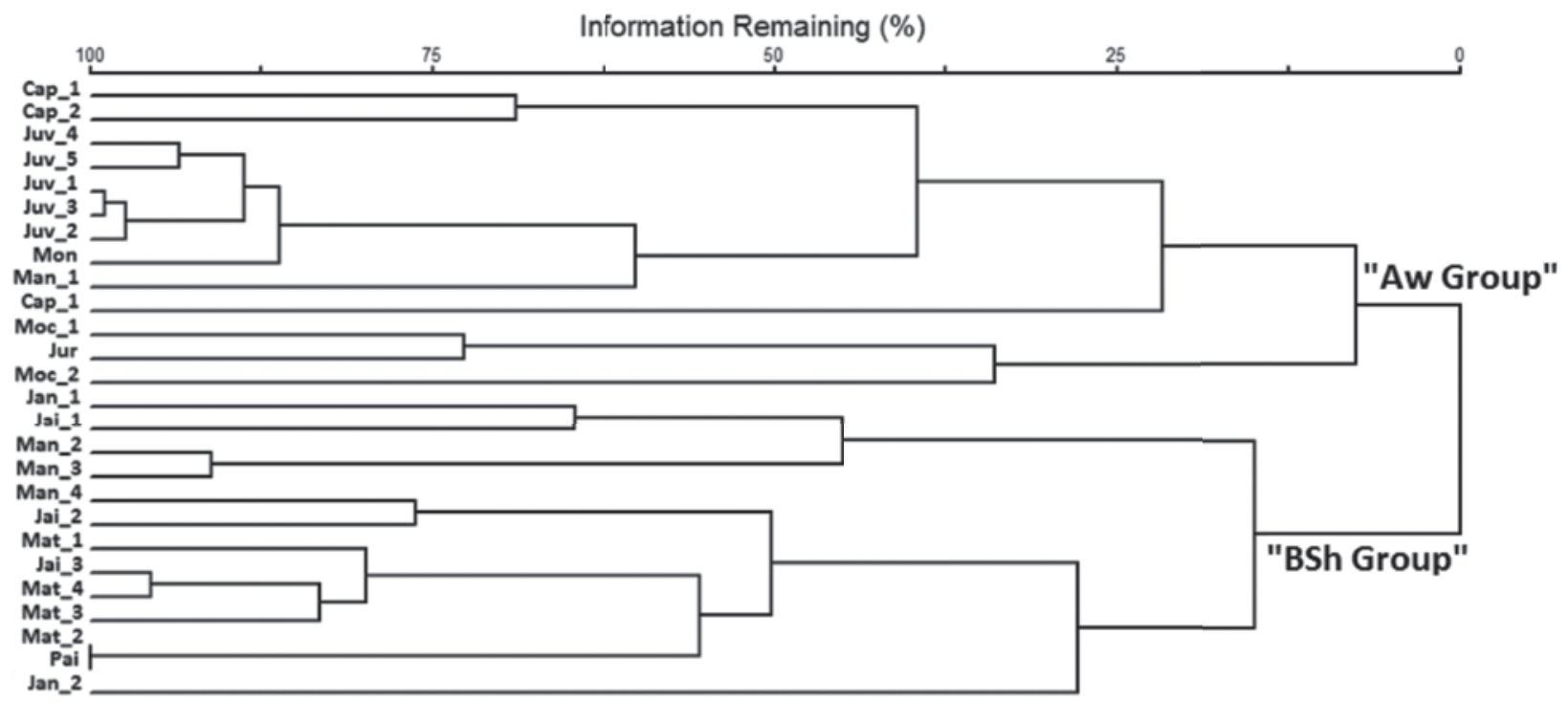

Figure 4 - Dendrogram of similarities between 26 areas of dry forest sensu stricto (DF) in northern Minas Gerais State, as formed by the agglomerative grouping analysis of 193 genera. The areas are identified by the codes listed in the Figure 1. BSh and Aw correspond to semi-arid and seasonal tropical climate domain, respectively.

related to an edaphic similarity between areas under contrasting climates, or to the ecotonal nature of these domains, otherwise artificially expressed by rainfall lines. Hence, abrupt limits between domains area not realistic. Besides, it is possible that the BSh domain extend further into the northern Minas Gerais, covering a much larger area of the sertaneja depression, as suggested by recent climatic data of rainfall and air temperature data (INMET 2011).

The 396 species considered in the present analysis indicated that the northern region of Minas Gerais State is an important ecotone possessing various vegetation forms. A large proportion of the species considered to be typical of dry forest (DF) also occur in other Brazilian phytogeographical domains, such as Caatinga (e.g. Commiphora leptophloeos, Piptadenia viridiflora, Cereus jamacaru and Spondias tuberosa) and Cerrado (e.g. Platypodium elegans, Sterculia striata, Machaerium acutifolium and Peltophorum dubium). They can also occur in the humid Atlantic forests (e.g. Tabebuia roseo- alba, Enterolobium contortisiliquum, Machaerium villosum and Eugenia florida) (Oliveira-Filho 2006, Forzza et al. 2010).

The presence of typical Caatinga species has led to the inclusion of DF within this domain. Consistently, Andrade-Lima (1981) described the forests associated with the calcareous soils as a southeastern transitional zone with the Caatinga biome, due to high deciduity and the presence of "bottle-shaped trees" such as Cavanillesia umbellata e Ceiba spp., besides many cacti species. Also, Ratter et al. (1978), in a study of Forests growing on mesotrophic soils, have considered the dry forests of Januária as a Forested Caatinga, since it presents species not found in other mesotrophic forests of Central Brazil. In this context, according with Andrade-Lima's Caatinga classification schemes, the DF of the present study corresponds to a vegetation-type 1, called "Tall Caatinga Forest".

In addition to their ample distribution in Brazil, most of the species mentioned in the present work also follow the distributions proposed by 
Prado and Gibbs (1993) and Prado (2000) for DF, including Amburana cearensis, Anadenanthera colubrina, Aspidosperma pyrifolium, Combretum leprosum, Commiphora leptophloeos, Enterolobium contortisiliquum, Machaerium acutifolium, Myracrodruon urundeuva, Peltophorum dubium, Piptadenia viridiflora, Pterogyne nitens, Ruprechtia laxiflora and Schinopsis brasiliensis. These species are present in diverse Neotropical localities, as in the Misiones and Piedmont central nuclei of the Chaco (Paraguay and Bolivia), and in dry valleys of the Andes; some extend to the Pacific and Caribbean coasts.

Some of the species considered typical of DF (e.g. Anadenanthera colubrina, Enterolobium contortisiliquum, Myracrodruon urundeuva, Combretum leprosum and Sterculia striata) or indicators of their groups (e.g. Tabebuia impetiginosa and Maclura tinctoria for the groups BSh and Aw respectively) were also indicated by Prado and Gibbs (1993) and Oliveira-Filho and Ratter (1995) as indicators of mesotrophic soils. As these species occur widely in the northern part of the state, it indicates that DF frequently grow on soils with moderate to high fertility. Similarly, Ratter et al. (1978) reported typical calcicolous species in Central Brazil, correlating the deciduousness with soil moisture regime.

Queiroz (2006), in a study of the floristic similarity of the Leguminosae of the Caatinga, indicated that DF could be found both on shallow soils over crystalline basement rocks or on very deep soils in the inland depression zone (e.g. Acacia langsdorffii, Amburana cearensis, Albizia polycephala, Bauhinia cheilantha, Senna spectabilis, Plathymenia reticulata, among others). The species cited by this author are similar to the species composing the BSh group, with very close relationships to the subgroup of DF growing on Red-Yellow Latosols (which includes the central depression zone). Queiroz (2006) also noted that the tallest forests are associated with richer soils derived from limestone formations, with common occurrences of the species Apuleia leiocarpa,
Goniorrhachis marginata, Copaifera langsdorffi, Enterolobium contortisiliquum, Pterogyne nitens, and Plathymenia reticulata, among others. In the present study, some of these species demonstrated a random patterns of occurrence, while others were restricted to the large Aw group associated with shallow limestone soils associated with the Bambuí Group.

The Aw group, more specifically the subgroup of the DF growing on Haplic Nitosols and Argisols, was separated from the other groups by a marked influence of typical Cerrado flora (e.g. Leptolobium dasycarpum, Curatella americana, Cybistax antisyphilitica, Eriotheca pubescens, Eugenia dysenterica, Dilodendron bipinnatum, Machaerium opacum, and Qualea grandiflora, among others). This fact demonstrates that the southern portion of the region comprises localities where the Cerrado domain greatly influences the DF floristic composition, explained by environmental similarities (both climatic and edaphic) between the two areas.

According to Oliveira-Filho et al. (2006), DF is part of the Atlantic complex forest gradient that begins with the ombrophilous formations of the coastal lowlands and becomes progressively seasonal towards the west, comprising semideciduous seasonal forests that transition to completely deciduous forests in the continental interior. This gradient is driven by the reducing water availability, increasingly seasonality. According to Andrade-Lima (1981), this continental gradient ends in the northeastern Brazil with scrubby, torny Caatinga formations.

In a continental scale perspective, high similarities between areas so widely separated, with endemisms and strong dissimilarity with neighbouring formations, all points to a new phytogeographic unit (Prado 2000). In the same scale, Oliveira-Filho et al. (2006) suggests observed that the main influence for the grouping with floristic similarity in DF is the geographic 
proximity; but when focusing on a given subregion, the predominant influence is then shifted to soil climate. A review of the flora of the Caatinga published by Sampaio (1995) described a very similar pattern for that vegetation type, noting that floristic similarities tend to be greater on different substrates in the same locality, then on similar substrates from distant localities. Consistently with our study, however, climate determines the grouping on a regional scale, but edaphic factors have a strong role at local scale, allowing to establish subgroups with separate floristic affinities.

The Aw group is formed by forest fragments associated with the tropical rainy climatic domain and comprises environments with higher annual rainfall and smaller seasonal and temperature fluctuations, contrasting with the group formed of fragments associated with the semi-arid climatic domain (group BSh). These Aw group fragments occur on shallower and often richer soils associated with strong environmental heterogeneity; topography is slightly more varied with a wide spectrum of landscapes of limestone's and siltstone/slate's outcrops that give way to a wide diversity of soils. The Cerrado domain flourishes under this same climatic regime, but mostly on deeper and poorer soils.

The BSh group comprises localities with greater average annual temperatures and with highly seasonal rainfall, below $750 \mathrm{~mm} /$ year (Antunes 1994). These forest fragments are present in the eastern part of the São Francisco River basin but do not cover extensive areas. They are associated with Alluvial (Fluvic Neosols), Planosols and Cambisols, which are eutrophic due the deposition of sediments from the São Francisco and Verde Grande Rivers. In strong pedological contrast, dry forest fragments cover extensive areas in the central depression and occupy old, deep, and well drained Red-Yellow Latosols. Virtually all Latosols are closely associated with the micro topography "Murundus", large termite mounds reaching up to 3 meters in height, and regularly distributed across the landscape.
The predominance and extensive occurrence of Red-Yellow Latosol with "Murundus" mounds in the northern part of Minas Gerais State indicates a previous wet phase of the Late Quaternary. At that time, the lowlands, valleys and depressions of the Verde Grande and São Francisco Rivers had climates that were much wetter than today, and probably occupied by extensive semideciduous forest formations. This period resulted in strong leaching and the development of deep Latosols. Virtually all Latosols associated with "Murundus" (now largely inactive) are also relics of this past humid phase.

It was not possible to evaluate the influence of historical uses of the DF fragments on their observed patterns of floristic similarity because very few sources in the database presented any such information. Hence, it is possible that some of the observed patterns of floristic similarity result from successional stages, of these DF.

It is important to state that most DF in this region has long been converted into agriculture or pasture, and only scattered fragments of secondary forests remain, most associated with limestone outcrops. The original tall forest, $25-30 \mathrm{~m}$ up to high, as described by former studies (Ratter et al. 1978, Andrade-Lima 1981 and Kuhlmann et al. 1994), are seldom found (e.g. some fragments of Juvenília (Santos et al. 2007), Capitão Enéas (Arruda et al. 2011) and Januária (D.M. Arruda, unpublished data).

\section{CONCLUSIONS}

The different climatic conditions (semi-arid and semi-humid) found in northern Minas Gerais favored the establishment of two distinct groups of dry forests sensu stricto (DF) that could be further subdivided in relation to their different soil classes.

The peculiarities and relations of $\mathrm{DF}$, at a regional scale, besides its floristic traits, long term evolution under contrasting climates, presence 
of endemics and dissimilarities with other neighbouring domains, all corroborate its identity as a separate phytogeographic unit.

The Latosols (deep-weathered soils) of the semiarid domain indicate a more humid paleoclimate during their formation, with corresponding semideciduous vegetation formations. Later, when semiarid climates established in the São Francisco/Verde Grande River Depression, these forest formations became progressively more deciduous, leading to the present-day distribution pattern.

\section{ACKNOWLEDGMENTS}

The authors thank Fundação de Amparo à Pesquisa do Estado de Minas Gerais (FAPEMIG) and Secretaria de Estado de Ciência, Tecnologia e Ensino Superior (SECTES-MG) for financing the project and for granting the scholarship for the first author. The authors also thank constructive comments of the two anonymous referees.

\section{RESUMO}

O Complexo Decidual que ocorre no norte do Estado de Minas Gerais, Brasil, levanta questões sobre a afinidade florística de suas formações, em relação aos domínios fitogeográficos vizinhos. Pouco se conhece sobre a identidade das formações de florestas estacionais que compreende esse complexo, ou sobre suas relações com os componentes abióticos, como solo, topografia e clima. O presente estudo objetivou reconhecer os padrões de similaridade florística de todos os fragmentos estudados de floresta decídua do Norte de Minas Gerais com atributos pedológicos e climáticos, com base no banco de dados disponíveis. Análises de agrupamento, indicaram a existência de dois grupos florísticos, os quais possuem clara associação com os domínios climáticos BSh (semi-árido) ou Aw (tropical chuvoso) de Koppen. As subdivisões desses grupos tiveram clara associação às classes de solos dominantes na região. Os Latossolos Vermelho-Amarelo são a classe de solo dominante no domínio climático BSh, seguidos por áreas aluviais associadas com Neossolos Flúvicos. O domínio Aw é compreendido por uma mescla de classes de solos diferenciados: Nitossolos, Argissolos, Cambissolos e Nessolos Litólicos, a maioria derivada dos calcários e ardósias da Formação Bambuí. A natureza ecotonal da região Norte do Estado de Minas Gerais propicia uma complexa interação da flora dos domínios fitogeográficos visinhos. Estes, somados aos fatores pedogeomorfológicos, possibilitaram melhor compreensão dos efeitos das mudanças climáticas do Quaternário tardio sobre a evolução do Complexo Decidual. Concluímos que os Latossolos do atual clima semi-árido (BSh) são relíquias de um clima úmido passado, durante o qual a expansão de florestas úmidas aconteceram. Mais tarde, essas florestas semidecíduas foram submetidas a um clima bem mais seco, quando a seleção da deciduidade levou ao cenário dos dias atuais no Complexo Decidual.

Palavras-chave: clima, floresta estacional decidual, ecótono, fitogeografia, solo.

\section{REFERENCES}

AB'SÁBER AN. 2003. Os domínios da natureza no Brasil: potencialidades paisagísticas. São Paulo: Ateliê Editorial, $159 \mathrm{p}$.

Andrade-Lima D. 1981. The caatinga dominium. Rev Bras Bot 4: 149-153.

Antunes FZ. 1994. Área mineira do Polígono das Secas; caracterização climática. Informe Agropecuário, Belo Horizonte 17: 15-19.

Arruda DM, Brandẽo DO, Costa FV, TOlentino GS, DuQue-Brasil RD, D'ÂNGElo-Neto S AND NunES YRF. 2011. Structural aspects and floristic similarity among tropical dry forest fragments with different management histories in North of Minas Gerais, Brazil. Rev Árv 35: 133-144.

BRANDÃO M. 2000. Caatinga. In: MENDONÇA MP AND LINS LV (Eds), Lista vermelha das espécies ameaçadas de extinção da flora de Minas Gerais. Belo Horizonte: Fundação Biodiversitas/ Fundação Zoo-Botânica de Belo Horizonte, p. 75-85.

FORZZA RC ET AL. 2010. Lista das espécies da flora do Brasil. Jardim Botânico, Rio de Janeiro. Available: < http:// floradobrasil.jbrj.gov.br/2010/>. Accessed: 05/06/2010.

Gentry AH. 1995. Diversity and floristic composition of neotropical dry forests. In: BULLOCK SH, MOONEY HA AND MEDINA E (Eds), Seasonally dry tropical forests. Cambridge: Cambridge University Press, p. 146194. 
HILl MO, BUNCE RGH AND SHAW MW. 1975. Indicator species analysis, a divisive polythetic method of classification, and its application to a survey of native pinewoods in Scotland. J Ecol 63: 597-613.

INMET - Instituto NAcional de Metereologia. 2011. $<$ http://www.inmet.gov.br/>. Accessed: 13/06/2011.

KUHLMANN E, BRANDÃO M AND LACA-BUENDIA JP. 1994. Considerações sobre a cobertura vegetal do estado de Minas Gerais. Daphne 4: 8-16.

Madeira BG, Espírito-SAnto MM, D’Ângelo-Neto S, NUNES YRF, SÁNCHEZ-AZOFEIFA GA, FERNANDES GW AND QUESADA M. 2009. Changes in tree and liana communities along a successional gradient in a tropical dry forest in south-eastern Brazil. Plant Ecol 201: 291304.

MCCunE B AND MefFord MJ. 2006. PC-ORD. Multivariate Analysis of Ecological Data. Version 5.10 MjM Software, Gleneden Beach, Oregon, USA.

Mello JM, Scolforo JRS and Carvalho LMT. 2008. Inventário Florestal de Minas Gerais: Floresta estacional decidual - Florística, estrutura, diversidade, similaridade, distribuição diamétrica e de altura, volumetria, tendências de crescimento e manejo florestal. Lavras: Editora UFLA, $266 \mathrm{p}$.

MuRPHY PG AND LUGO AE. 1986. Ecology of tropical dry forest. Annu Rev Ecol Syst 17: 67-88.

OliveIRA-FILHO AT. 2006. Catálogo das árvores nativas de Minas Gerais: mapeamento e inventário da flora nativa e dos reflorestamentos de Minas Gerais. Lavras: Editora UFLA, $423 \mathrm{p}$

OLIVEIRA-FILHO AT AND FONTES MAL. 2000. Patterns of floristic differentiation among Atlantic Forests in Southeastern Brazil and the influence of climate. Biotropica 32: 793-810.

OLIVEIRA-FILHO AT, JARENKOW JA AND RODAL MJN. 2006. Floristic relationships of seasonally dry forests of eastern South America based on tree species distribution patterns. In: PENNINGTON RT, LEWIS GP AND RATTER JA (Eds), Neotropical Savannas and Dry Forests: Plant Diversity, Biogeography, and Conservation. Oxford: Taylor \& Francis CRC Press, p. 59-192.

OLIVEIRA-FilHo AT AND RATTER JA. 1995. A study of the origin of central Brazilian forests by the analysis of plant species distribution patterns. Edinb J Bot 52: 141-194.
PENNINGTON RT, LEWIS GP AND RATTER JA. 2006. Neotropical Savannas and Dry Forests: Plant Diversity, Biogeography, and Conservation. Oxford: Taylor \& Francis CRC Press.

PRADO D AND GIBBS P. 1993. Patterns of species distributions in the dry seasonal forests of South America. Ann Mo Bot Gard 80: 902-927.

PRADO DE. 2000. Seasonally dry forests of tropical South America: from forgotten ecosystems to a new phytogeographic unit. Edin J Bot 57: 437-461.

RATTER JA, RichaRdS PW, ARGENT G AND GIFFORD DR 1978. Observations on forests of some mesotrophic soils in central Brazil. Rev Bras Bot 1: 47-58.

RodAl MJN, BARBosA MRV AND ThOMAS WW. 2008. Do the seasonal forests in northeastern Brazil represent a single floristic unit? Braz J Biol 68: 467-475.

QueIroz LP. 2006. The Brazilian Caatinga: Phytogeographical Pattern Inferred from Distribution Data of the Leguminosae. In: PENNINGTON RT, LEWIS GP AND RATTER JA (Eds), Neotropical Savannas and Dry Forests: Plant Diversity, Biogeography, and Conservation. Oxford: Taylor \& Francis CRC Press, p. 113-149.

SAles HR, SOUza SCA, Luz GR, MORAIS-Costa F, Amaral VB, SANTOS RM, VEloso MD AND NunES YRF. 2009. Flora arbórea de uma Floresta Estacional Decidual na APA Estadual do Rio Pandeiros, Januária/MG. MGBiota 2: 31-41.

SAMPAIO EVSB. 1995. Overview of the Brazilian Caatinga. In: BULLOCK SH, MOONEY HA AND MEDINA E (Eds), Seasonally dry tropical forests. Cambridge: Cambridge University Press, p. 34-63.

SANTOS RM, VIEIRA FA, FAGUNDES M, NUNES YRF AND GUSMÃO E. 2007. Riqueza e similaridade florística de oito remanescentes florestais no Norte de Minas Gerais, Brasil. Rev Árv 31: 135-144.

SNEATH PHA AND SOKAL RR. 1973. Numerical Taxonomy. San Francisco: WH Freeman, 573 p.

VELOSO HP, RANGEL-FILHO ALR AND LIMA JC. 1991. Classificação da vegetação brasileira, adaptada a um sistema universal. Rio de Janeiro: IBGE, 123 p. 